\title{
GLOBALISATION AND INDIVIDUALISATION IN LATE MODERNITY: A THEORETICAL INTRODUCTION TO THE SOCIOLOGY OF YOUTH ${ }^{1}$
}

\author{
Frédéric Vandenberghe*
}

\begin{abstract}
Resumo: $\mathrm{O}$ artigo oferece uma análise programática de algumas das principais teorias da modernização, da globalização e da individualização na modernidade tardia, conectando essa análise à sociologia da juventude. $\mathrm{O}$ texto se divide em quatro partes: a primeira provê um panorama dos debates sobre a modernidade, distinguindo várias posições no seio destes (clássica, anti, pós e neo); a segunda parte propõe um quadro de referência multidimensional para a análise da globalização, o qual integra seus aspectos econômicos, políticos e culturais em uma narrativa coerente; a terceira parte apresenta as teorias da sociedade de risco, da modernização reflexiva e da individualização reflexiva de Ulrich Beck e Anthony Giddens; finalmente, a última parte costura todos os fios da análise em uma teoria sociológica da juventude, do pós-materialismo e dos novos movimentos sociais.
\end{abstract}

Palavras-chave: Globalização; modernização; individualização; novos movimentos sociais; juventude.

Abstract: This article provides a programmatic analysis of some of the main sociological theories of modernization, globalization and individualization in late modernity and connects the analysis to the sociology of youth. The article is divided in four parts: The first part gives an overview of the debates about modernity and distinguishes various positions within it (Classic, anti, post and neo); the second part proposes a multidimensional framework for the analysis of globalization that integrates the economic, political and cultural aspects into a coherent narrative; the third part presents the theories

* PhD in Sociology at École des Hautes Études en Sciences Sociales, Paris, France. Post-doctoral degree at Istituto Italiano Firenze (Firenze, Italy), University of Humanistic Studies (Netherlands) and University of California, Berkeley (United States of America). Professor and researcher at Instituto de Estudos Sociais e Políticos (IESP), Universidade do Estado do Rio de Janeiro (UERJ), Rio de Janeiro, Brasil. E-mail: frederic@iesp.uerj.br. 1 The text was originally written in 1998 in English. It was translated and published in Italian, but the manuscript itself remained filed in my 
of the risk society, reflexive modernization and reflexive individualization of Ulrich Beck and Anthony Giddens; finally, the last part ties together all the strands of the analysis in sociological theory of youth, postmaterialism and new social movements.

Keywords: Globalization; modernization; individualization; new social movements; youth.

There's no sociology of youth without 'sociological imagination'. With some exaggeration, we could say that C.W. Mills's Sociological Imagination (MILLS, 1959) represents the sociological counterpart of Kant's Critique of Pure Reason. In the same way as the empirical reality can only be understood thanks to the mediation of the categories of understanding, the tribulations of contemporary youth can only be understood if their everyday life is seen against the larger socio-historical background of late modernity. Uncoupled from this socio-historical background, the sociological analysis of youth risks to remain stuck in the ethnographic description of life histories and lifestyles, or even worse, in the thoughtless manipulation of statistical correlations and regressions. In order to overcome this empiricist tendency

personal archives till Danilo Arnaut invited me to publish it in Idéias. By sheer coincidence, and independently from Danilo, Carusa Gabriella proposed to translate the text, which will almost simultaneously appear in Portuguese in Revista Mediações. I thank both Danilo and Carusa for their solicitude. I have tried to update the text a little bit, but not to relocate and adapt it to the Brazilian context. If the text still has any value after all these years, it is, I suppose, because, like Anthony McGrew's text of 1992 which inspired me (as well as Beck, 1997), it proposed an organising framework for the analysis of globalisation and individualisation in late modernity. the local or the local and the global, to use more current language, can be meaningfully interconnected in such a way that youth is no longer seen as a marginal'subject', inthedoublesenseofbeingahistoricalactorwithoutpowerand a specialised area of research which is cut off from the cutting edges of sociological theory. 
towards the fetishist accumulation of brute data, which only make sense as post-positivist philosophers well know because they are "overdetermined" by theory, I will be concerned in this article with the outline of a theoretical framework for the analysis of youth. Eventually, this theoretical framework, which is among others inspired by Ulrich Beck and Anthony Giddens' overlapping theories of late modernity, will allow us to see how Mills's categories of the personal and the socio-historical, or the local or to bring the 'marginal subject' back to the center of social life and of sociological theory, I propose to reconnect the sociology of youth to the sociology of social change in general and of late modernity in particular. The article is divided in four parts. In the first part, I present a quick overview of the theories of modernity which have succeeded each other since the birth of sociology in the nineteenth century. The succession of the theories of modernity, which is mnemonically indicated by the prefixes classic, anti-, post-, neoand late-, offers a kind of knowledge-political preamble to a synthetic theory of late modernity. This theory of late modernity forms the background for the analyses of the dual processes of globalisation and individualisation, which are respectively analysed in parts 2 and 3. The main idea which underlies and connects the analyses of globalisation and individualisation together is that a critical sociology of late modernity has to be multidimensional (VANDENGERGHE, 1997-1998). It cannot content itself with a structural analysis of global domination but has to indicate possible forces of emancipation as well. In the same way as a macro-sociology of the system needs to be complemented with a micro-analysis of the life-world, the analysis of the economically driven processes of globalisation has thus to be augmented with an analysis of the emancipatory processes of individualisation, which are going on at the same time in the local life-worlds and which could potentially inflect the processes of globalisation in the direction of a post-materialist order of sustainable development 
which is both socially sensitive and ecologically responsible. ${ }^{2}$ At this point, youth will be brought in. In part 4, I will analyse the situation of youth in late modernity and show how the double process of globalisation and individualisation affect the transitions to adulthood and life-politics. Youth will thus not be considered as a biological category but first as a sociological one, defined in terms of status transitions, and then as a cultural and political one, defined in generational terms as an instantiation of the new social and cultural movements which struggle for the normative orientations that determine the direction of social development.

\section{Modernity: Classic, Modern, Anti, Post, Neo and Late}

Sociology emerged in the long nineteenth century (17891914) with the advent of modernity and cannot be uncoupled from it. Given that sociology is reflexively tied to modernity and that modernity is intrinsically associated with socio-cultural dynamism and the 'creative destruction' of the remnants of the past (BERMAN, 1982), it is no surprise that the analysis of social change has been one, if not the central topic of sociology. The disciplinary distinction between anthropology, understood as the study of 'societies without history' (Levi-Strauss), and sociology, understood as the study of modernity, may (and must) be overhauled, but it nevertheless makes the link between historicity, social change and modernity explicit. Looking back at the history of sociology, which can also be read as a theoretical transcription of social change of the last two centuries, we can distinguish at least five distinctive theoretical-cum-ideological

\footnotetext{
${ }^{2}$ By using the subjunctive, I want to indicate and explore the potential of counterfactual developments grounded in the life-world. Needless to say, the counterfactual mode of thinking has mainly a heuristic and deontological function: extrapolating from the present to the future, it points to what could and should happen if certain circumstances which are not realised at the present were actually realised
} 
periods of theorising about social change ${ }^{3}$ : (i) the classic theory of modernity, as formulated by the 'founding fathers' of sociology; (ii) the post-war theory of modernisation and its ideological inversion in the anti-modernization theory of the sixties and the seventies; (iii) the post-modern theory of the eighties, (iv) the neomodern theory of democratisation and, last but not least, (v) the sociological theory of late modernity, which I consider a critical synthesis of the aforementioned theoretical strands. (Since the turn of the millennium, the world is in turmoil. The conjunction of geopolitical, economic and technological revolutions is changing the contours of the world as we know it. Although I now think that the social changes are so momentous to warrant affirmations that late modernity has now reached its course and that we are facing the emergence of a new civilization (VANDENBERGHE, 2014, pp. 265-329), I do not pretend to be able to decipher the current conjuncture. I even doubt that sociology, steeped as it is in the nineteenth and twentieth century, is particularly well placed to propose an ontology of the present. Those are transitional times. Like of most of us I am in the fog. To be cautious, I therefore ask the reader to consider my analysis as an analysis of the recent past - valid till 2007 perhaps, but not beyond).

(i) Classic: In the classic period (1840-1933), each of the founding fathers of sociology - Emile Durkheim, Karl Marx, and Max Weber - presented a 'discontinuist interpretation of modern history' according to which the advent of modernity represents such a significant break with the past that the societies which

\footnotetext{
${ }^{3}$ Those successive periods of theorising about modernity can be indicated by the mnemonic device of the 5 prefixes: Classic-, anti-, post-, neo- and late(ALEXANDER, 1994). In so far as the succession of theories also reflects sociohistorical change, the prefixes are not only meant to refer to historically variable modes of reading but also to change of socio-historical modes of being. The main advantage of such a double conceptualisation of modernity along an interpretative and a socio-historical axis is that it allows for the juxtaposition of modes of reading and modes of being. Adopting this perspective, one can thus not only offer, say, a post- (or anti-)modern reading of classic modernity, but also a classic (or late) modern reading of postmodernity.
} 
emerged in the West in the eighteenth and nineteenth century are really and radically distinct from all prior forms of social order (GIDDENS, 1985: 31-34; 1990: 1-6). Although they don't agree about the specifics and identify different processes of modernisation, respectively functional differentiation, commodification and rationalisation (CROOK, PAKULSKI and WATERS, 1992: 2-9), we can nevertheless be confident that the processes of long-run social change which they describe are largely complementary and that their analyses of modernity converge in a grand empirical narrative of historical social change. In this grand narrative, the relative autonomisation of functionally differentiated social structures, like the market economy or the bureaucratic administration of the state, and the progressive erosion of tradition and the natural bonds of solidarity, appear as the distinguishing characteristics of the 'Great Transition' towards modernity.

Combining a general theory of modernisation with a critical diagnosis of the ambivalence of modernity, the founders of sociology considered the general diffusion and generalisation of the purposively rational or strategic mode of action from the economic sphere to all other spheres of life as the main culprit of the pathologies of modernity (HONNETH, 2000: 11-69). Indeed, without too much hesitation, we could even say that sociology was from its very beginning involved in a combat against the theoretical and practical hegemony of utilitarianism (CAILLÉ, 1988: 24-32). Contesting the spread of utilitarian individualism, the classical tradition of sociology was engaged in a political attempt to reinvigorate and defend an ethically inspired 'institutional individualism' (Durkheim), which is able to combine the freedom of modernity with the solidarity of the past.

Notwithstanding those commonalities, it should however be noted that Durkheim and Mauss's diagnosis of the pathologies of modernity differed significantly from that of their German counterparts. If Weber and Marx were above all concerned with the potential loss of personal freedom, Durkheim and his nephew put more stress on the loss of community and solidarity. In the first case the autonomisation of the functionally differentiated social 
structures, systemically constraining the individuals from without and imposing a strategic mode of action on them, was seen as a threat to the autonomy of the individual (alienation); in the second case, the predominance of strategic action was seen as linked to the dissolution of solidarity (anomie).

(ii) Anti: Giving an optimist twist to the classic interpretations of modernity, the theory of modernisation which emerged in the post-war period and of which Talcott Parsons $(1966,1977)$ is one of the main representatives presented an evolutionary view of social change. According to Talcott Parsons (and a few others like-minded spirits, such as Daniel Lerner, Marion Levy, Alex Inkeles, S.N. Eisenstadt, Walt Rostow and Clark Kerr), all modernising societies were destined to follow a similar path of non-revolutionary incremental change and to undergo a steady but stepwise linear process of increased general adaptation ('adaptive upgrading') through functional differentiation and integration of their subsystems which allows the system to control more and more successfully its environment. From this evolutionist and slightly teleological perspective, all societies were seen as moving and converging towards the high degree of industrialisation, secularisation and democratisation which Parsons saw exemplified in the United States of the sixties. Modernisation theory offered not only an analytical framework but in so far as it excluded alternative pathways to modernity it was also a justification of the status quo.

Due to a change in the intellectual and ideological climate, modernisation theory was largely rejected in the later sixties, both on empirical and ideological grounds (KNÖBLE, 2001). The new generation of critical theorists came to consider Parsons' unilinear and teleological interpretation of world history as a thinly veiled ideology of the status quo and American imperialism. While dependency theory rejuvenated the old Leninist argument that the prosperity of the capitalist societies is purchased at the expense of the impoverishment of large areas of the remainder of the world (COCKROFT, FRANK and JOHNSON, 1972), Barrington Moore argued that dictatorship and not democracy was spreading throughout the world (MOORE, 1966). As a result, Parsons' ‘world 
growth story' was dropped as an ideologically laden Eurocentric grand narrative, and eventually his theory of evolution and modernisation came to be replaced by a Marxist theory of revolution and counterrevolution. Some of Parsons' critics even went so far as to reject the process of modernisation as such. The members of the Frankfurt School, for instance, simply inverted the optimism of modernisation theory: industrialisation does not lead towards democracy and freedom, but towards increased domination and alienation of the masses.

(iii) Post: Later onwards, in the eighties, when the revolutionary enthusiasm of the seventies had vanished, postmodernism emerged on the academic scene. The post-modernists radicalised the Frankfurt School critique of instrumental reason and seemed to give up the project of modernity altogether. Post-modernism is however an ambiguous and essentially contested concept. In order to clarify its meaning and to avoid confusion between the different brands of 'post-ism', I propose to categorically differentiate postmodernism (a), post-modern social theory (b), and post-modernity (c). Those terms are not equivalent, but occur in the three different but overlapping discursive contexts of cultural theory, philosophy, and sociology in which the so-called 'post-modern turn' is said to have taken place.

(a) Post-modernism: The debate about post-modernism plays an important role in the field of cultural theory, aesthetics and architecture (CONNOR, 1989, HARVEY, 1989: Part 1, LASH, 1990: Part 2, JAMESON, 1991). Here the debate revolves around distinctions between modernism and post-modernism in the arts. Modernism represents the culmination of the process of social differentiation and autonomisation in which the aesthetic sphere, and each of its sub-fields (painting, sculpture, literature, theatre, architecture, film, etc.), follow their own immanent laws (e.g. l'art pour l'art, the house as a machine for living, etc.). Innovation and formal rationalisation are the norms of the modernist avantgarde. Postmodernism reacts against this autonomisation of the cultural sphere and pleads for its dedifferentiation so that the 
'Great Divide' between high art and popular art can be overcome and that the cultural sphere can be reconnected to the life-world, even to the point that the life-world itself, invaded and colonised by commodified products of an anti-auratic mass-culture, becomes an aspect of post-modern culture.

(b) Post-modern social theory: The discourses of the post-modern also appear in the field of philosophy and social, psychological and cultural theory as well (HABERMAS, 1985, DEWS, 1987, BEST and KELLNER, 1991). Post-modernists criticise the rationalist assumptions of modern philosophy and social theory - ranging from the philosophical project of Descartes, Kant and Hegel to the social theories of Marx, Durkheim, Weber and Habermas, whom they often conceive as the arch-modernist whose work deserves to be deconstructed. Post-structuralist philosophers like Lyotard, Derrida, Deleuze, Baudrillard, Vattimo and a few others, inspired by Saussure, Nietzsche and Heidegger, variously criticise modern theory for its search for a foundation of knowledge, for its universalising and totalising claims, and above all for its fallacious rationalism and logo- (if not phallo) centrism. They also provide a critique of representationalism and the modern belief that theory mirrors reality, adopting instead the relativist position of feminist and post-colonial standpoint theory, possibly combining it with a deconstructive hermeneutics which argues that all cognitive representations of the world are historically and linguistically mediated.

(c) Post-modernity: Discourses on post-modernism also appear in sociological and political economic discourses that claim to identify a basic epochal transition from modernity to a new stage of history (HARVEY, 1989: Part II and III, SMART, 1992, WEBSTER, 1995). Analysing the growing predominance of the media and information technology, the growth of the service and the knowledge sector, and the changes in the regime of capital accumulation, several analysts have advanced the claim that we now have reached a new stage in history beyond modernity (if not beyond history altogether) and that we now live in a new sort of 
society which they variously label as post-modern, post-industrial or post-Fordist.

(iv) Neo: Since the fall of the Berlin wall, modernisation theory has somehow returned with a vengeance (SZTOMPKA, 1993: 129141). The protracted "third wave of democracy" (Huntington), which started in Western Europe in the 1970's (Portugal and Spain), continued in Latin America (Brazil, Argentina, Chile) and Eastern Europe (Poland, Germany, Hungary) in the 1980's and finds its provisional conclusion in the Middle East following the 'Arab spring', shows that the old liberal themes of Parsons's modernisation theory have neither lost their political actuality, nor their ideological force. The free market, the rule of law and above all parliamentary democracy are not just ideologies of the status quo, as the anti's claim, nor metanarratives which have to be deconstructed, as the post-modernists claim, but provided that they are adequately reformulated in a neo-functionalist framework, they can be seen as so many 'evolutionary universals' which the democratic revolutions aimed to institutionalise by means of the ballot. Extrapolating from the East to the West and beyond, we can see that the revolt of the 'really existing individuals' against communist regimes (in Eastern Europe) and military dictatorships (in Western Europe and Latin America) have opened new perspectives of a global and coordinated democratic struggle for the realisation and institutionalisation of post-materialist values. The new social movements, which have emerged in the struggle against authoritarian regimes, fighting successful revolutions not for socialism but for democracy, solidarity and the defence of the life-world, were animated by the radical appeal of democracy. The revival of the eighteenth century concept of civil society, understood as a self-regulating public sphere which mediates between the private sphere on the one hand and the state and the market on the other hand (COHEN and ARATO, 1992), is linked to the post-materialist re-evaluation of universalism. In so far as universalism is no longer considered as something which is essentially repressive, but as a value that animates the democratic struggle which the new transnational social movements wage both 
against the state and the market, we can indeed say that we are witnessing a gradual shift from post- to 'neo-modernism'.

(v) Late: The notion of late modernity is used here as synthetic signifier of a sociological theory of the global present which aims to bring home the harvest of the classic, anti, post and neo-modernisation theories. The theory of modernity, which dialectically overcomes the limits of each of the preceding theories, is meant as a general framework of guidelines for the analysis of the dual processes of globalisation and individualisation, which will be presented in part 2 and 3 of the article and which form the backbone of the analysis of the sociology of youth, which will be presented in part 4.

- Inspired by the classic project of sociology, the theory of late modernity aims to critically sift through the theories of Marx, Durkheim and Weber in order to update them and thus to make them relevant for the present time. With the benefit of hindsight, we can now see that the radicalisation of modernity has led to a situation which the founding fathers had not foreseen. First of all, they did not anticipate that the compression of time and space would lead to a global world in which the social processes are economically, politically and culturally interconnected. Secondly, they were somewhat too optimistic about the prospects of industrialism and did not anticipate the ecological limits of economic growth. Thirdly, although the founding fathers agreed in their critique of utilitarianism and insisted on the necessity to reinvigorate the social tissue, neither Durkheim, who stressed the threat of anomie, nor Marx and Weber, who were more concerned with the threat of alienation, did envisage the possibility that anomie and autonomy would be brought together in the ethics of the post-materialist youth and the politics of the new social movements.

- Although the sociological analysis of late modernity is definitely post-Marxist in inspiration, the prefix 'late' is intentionally used here as kind of tribute to neo-Marxist analyses of 'late capitalism' (ADORNO, 1972). The series of crises that have 
plagued the semi-periphery of the world system since the 1980's have by now reached the center of the system. The subprime crisis of 2007-2008, which morphed into a fiscal crisis when it reached Europe, shows that capitalism is not as secure as it once seemed. Although industrial capitalism is now spreading worldwide, as was anticipated by Marx and Engels in the Manifesto of the Communist Party, the sociology of late modernity unmasks the claim that there is no functional alternative to the free market as part and parcel of the neo-liberal ideology and its attack on the welfare state. Critically analysing the radical economic, political and cultural transformations which societies worldwide are undergoing, it aims to explore the possibility of the emergence of transnational new social movements that would challenge the social consequences of the neo-liberal hegemony.

- The sociology of late modernity is definitely not a postmodern sociology. Relinquishing the attractions of postmodern social theory, it works instead towards a sociological account of postmodernism and postmodernity. The sociology of late modernity agrees with the postmodernists that contemporary mass culture is essentially postmodern, but against them, it links the postmodernist regime of signification to the post-Fordist regime of accumulation and sociologically decodes postmodernism as the cultural expression of late modernism. The sociology of late modernity categorically rejects the antifoundationalist and antisystematic trust of postmodern social theory. However, in so far as it transforms postmodern social theory from a resource into a topic of sociological analysis, it transposes the scepticism of the postmodern philosophers to the life-world in order to 'refunctionalise' the postmodern critique of authority into the fulcrum of a social critique of the politics of industrial society.

- As the postmodernist interpretation of the world as a local, privatised and fragmented place gives way to an analysis of the economic forces that shape the global world and of the political forces that seek to reshape it, the theory of late modernity willingly follows neo-modernisation theory by placing democracy back on the agenda. The discussion of reflexive modernisation, 
individualisation, youth and the new social movements, which I will present in the last part of this article, is in line with this shift and conceived as a humble contribution to it.

\section{Economic, Political and Cultural Globalisation}

\subsection{What is globalisation?}

Post-modernism was the fad of the eighties. Since the beginning of the nineties, globalisation theory has become an increasingly influential paradigm, even to the point that it can be considered as the 'successor to the debates on modernity and postmodernity' (FEATHERSTONE and LASH, 1995: 1). Globalisation refers to the social processes of 'time-space compression' (HARVEY, 1989: 240) in which the 'constraints of geography on social and cultural arrangements recede and people become increasingly aware that they recede' (WATERS, 1995: 3). As time and space become separated from local contexts and standardised by maps and clocks, individuals are able to communicate with each other across temporal and spatial distances. The world 'shrinks' as it were. Continuous and instantaneous interconnections between distant locations transform the latter into nodes of a single network. 'The intensification of worldwide social relations, says Giddens, link distant localities in such a way that local happenings are shaped by events occurring many miles away and vice versa' (GIDDENS, 1990: 64). As the local and the global become dialectically intertwined, local actions and global structures become mutually implicated in such a way that local actions reproduce or transform the global structures in which they are embedded and by which they are increasingly conditioned. Transposed from the metatheoretical realm to the socio-historical realm, structuration or the dialectical interplay between action and structure (GIDDENS, 1984) thus takes on a global dimension. In the same way as every individual speech act presupposes the social institution of language and contributes to its reproduction or 
transformation, every local act is potentially conditioned by global structures and implicated in their transformation or reproduction. The important points to stress here are that this dialectic between the local and the global is not one- but two-sided, and that it can have far reaching social and political implications: global structures do affect local actions but in so far as the former presuppose the latter and are dependent on them, local actions can have a significant impact on global structures.

The analysis of the multiplicity of linkages and interconnections that transcend the nation-states which make up the emerging modern world system has recently been brought to the centre stage of the social sciences thanks to their attempts to theorise globalisation (FEATHERSTONE, 1990; McGREW, 1992; ROBERTSON, 1992; FEATHERSTONE, LASH and ROBERTSON, 1995; WATERS, 1995; AXFORD, 1995; ALBROW, 1996; McGREW, 1997; BECK, 1997, 1998a, b). Although some debate is still going on about the periodisation of the onset of the global shift, all protagonists of the globalisation debate seem to agree that the scope (or 'stretching') and the intensity (or 'deepening') of the processes of inter - and transnationalisation have so significantly increased in the last quarter of the century that a global civilisation is now on the verge of emerging. Objectively, the economic, political and cultural subsystems are interconnected and interdependent as never before; subjectively, we are increasingly conscious of the world as a whole. As media products circulate in an international arena, humanity is able to observe itself in its globality. Somewhat more speculatively, speaking like the old Hegel, we could refer to the objective side as "globalisation an sich" and the subjective side as "globalisation für uns" and argue that the current interconnection between things and people trigger a global process of morphogenesis in which society, culture and personality are all transformed at the same time, leading to "globalisation an sich und für uns".

On the map, the boundaries between countries are as clear as ever. And yet a closer look at contemporary economic, political and cultural interconnections reveals that those boundaries have 
become largely porous and permeable, at least in the West and for the elites, as the phenomenon of globalisation is by no means experienced uniformly across the globe or across class. Immense 'flows of capital, money, goods, services, people, information, technologies, policies, ideas, images and regulations' (LASH and URRY, 1994: 280) transcend individual nation-states and dissolve their borders. Borders become so to speak optional, though, unfortunately not for immigrants. Locally bound with their feet to the ground, individuals can think, dream, read, invest, and communicate globally without the least being hindered by borders. Thinking globally is no longer a privilege of diplomats, astronauts and bankers. For young people, who are brought up with and socialised by TV and the internet, society is from the very beginning experienced as a 'world society' without borders, which does not mean that place looses its importance, but that even without knowing it, their stream of consciousness has a global dimension.

Arguably, globalisation processes are driven forward by the economy. The entire globe is now operating within the framework of a single capitalist world-economy. The economic flows of capital, labour, commodities, information and images cross the borders without major control (see 2.2). The expansion of the capitalist world market is accompanied by the decline of the nation-state and its power to control the flow of goods, people, information and various cultural forms. Relations between nongovernmental actors like international organisations, transnational corporations and transnational social movements now supplement intergovernmental relations between nation-states (see 2.3). In addition to the development of a capitalist world-economy and a shifting system of nation-states, the rise of global culture is an especially salient feature of contemporary globalisation. Global culture is ambiguous, however: it involves the worldwide diffusion of capitalist cultural products and the spread of the consumerist ideology as well as the local interpretation and indigenisation of those global cultural products (see 2.4). Global cultures and cultural products permeate local ones, colonising them as much 
as providing them with forces of resistance against colonisation. In any case, global culture makes individuals reflexive: confronted with a plurality of possible lifestyles and life forms, they have to choose, produce and cobble together their own biographies. And given that they choose consciously and that the local is dialectically intertwined with the global, the aggregation of private life choices can have far reaching political implications, as we will see later when we analyse the role of youth and social movements.

\subsection{Economic Globalisation}

Although the impact of the forces of globalisation is most strongly felt in the domain of economics, it is important to consider the process of globalisation as a multidimensional phenomenon and to avoid reducing it to its sole economic dimension. Globalisation is not just about the expansion of free trade and competition in a global market but involves a process of overall social change whereby the local and the global are mutually implicated. Those economists who stress the economic dimension of globalisation at the expense of its other dimensions, such as the political, ecological, cultural, civil societal and legal ones, do not see the political and ideological implications of their analyses. In so far as their models systematically ignore the extra-economical conditions of the free market, they endorse and performatively reinforce the neo-liberal ideology according to which the laws of the free market actually represent the only possible mode of global governance. However, if one adopts the political and sociological perspective and submits the economist's laws of the global market to a defetishising critique, one sees that those laws are only able to systemically regulate and coordinate a multiplicity of local actions on the condition that they are left to be free and that no social and political factors impinge on the closure of the economic system. The analysis of those extra-economic conditions of the autopoetic closure of the economic system defetishises the laws of the market and reveals that neo-liberalism is not simply an economic doctrine but involves a political project. Indeed, as Bourdieu says, 
|131|

Frédéric Vandenberghe

neo-liberalism is a scientific program of knowledge converted into a political program of action which aims to create the conditions of the realisation of its 'theory' through the methodical destruction of the collective structures which are able to hinder the logic of the pure market' (Bourdieu, 1998:109).

In so far as neo-liberalism only recognises individuals, the political realisation of its economic theory involves the systematic atomisation of the social, that is the reduction of collective structures to exploitable individuals strategically competing for scarce resources. As a result of the dismantling of the collective structures, individuals, and especially the younger ones whose wages are individualised and whose working times are flexibilised, become so to speak a variable and exploitable input factor of the economic system.

Although the idealtype of a truly globalised free market economy has not yet been realised in practice (HIRST and THOMPSON, 1996), the 'myth of globalisation' is constantly invoked by the 'transnational capitalist class' (SKLAIR, 1991: 70$72,133-137)$ as a weapon in its struggle for profits to flexibilise the process of production and to deregulate the labour market. The argument is always the same: in order to remain competitive on an international scale, the marginal productivity of labour has to be increased, and this, as we shall see, can only be done in 3 ways: by reducing labour costs, which implies the dismantling of the welfare state (1), by substituting capital equipment for workers, which means the introduction of new technology (2), and by re-engineering the workplace, which involves the flexible rationalisation of the organisation (3). In all cases, the likely result of the implementation of neo-liberal policies is highly skewed in the direction of a global 'dual society' with record benefits for the winners of globalisation - the 'globals' who are mobile-, and mass un - and underemployment for the losers - for the 'locals' who are confined to their quarters (BAUMAN, 1998:6-26). Inequality increases, so does exploitation, and what appears as a non political 
shift to market governance amounts in fact to a politicisation of society which is masked by an appeal to the irresistible forces of the global market. Although the effects of economic globalisation affect people of all ages, it is clear that young people are especially vulnerable to the capitalist strategies of global flexibilisation of the workforce. Continually faced with the prospect of unemployment, they extend their studies, become flexible, work in the periphery of the labour market, accept low wages and variable working hours, and end up blaming themselves if they cannot secure a stable position on the labour market.

(1) Dismantling of the welfare state: Multinational enterprises and transnational corporations organise their production, marketing and distribution on a global basis. Their activities are predominantly geared to increase their profitability and to maximise their international competitive position. In so far as national subsidiaries operate in the context of an overall corporate strategy, national labels literally loose their signification and become fetishes, in the Marxist sense of the word, disguising the transnational accumulation of capital and the international division of labour in the idiom of national control and territorial sovereignty (APPADURAI, 1990: 306-307). Organised within the framework of the international division of labour, production is split into fragments and assigned to whichever part of the world that provides the most profitable combination of capital and labour. Production is thus delocalised, and plants are installed where labour costs are minimal. The result is not only that the multinationals are in a position to play nation-states against each other and to bargain for fiscal incentives, subventions and infrastructural opportunities, but also that they put the national governments under pressure to dismantle the welfare state and to abolish social rights and guarantees. Transnational capital has thus become genuinely footloose, but at the same time it is undermining democracy and welfare state: delocalising its production, it creates massive unemployment at home but refuses to pay for it. All this is happening without discussions in parliament, without decisions by the government and without changes of the law, amounting 
thus to what Beck calls a 'global subpoliticisation' of society, 'politicising society through a depoliticisation of the state' (BECK, 1997: 176).

(2) Introduction of new technology: In 1974, Daniel Bell forecasted the coming of the 'post-industrial society', of a society which is driven by the 'axial principle' of knowledge and dominated by the service economy. Comparing the industrial society, which is dominated by manufacturing, to the post-industrial one, Bell identifies five major changes (BELL, 1974: 14-33): i) The sources of innovation are increasingly derivative from scientific research and technological development. ii) While the development of science and technology stimulate economic growth, technological growth itself is now controlled and systematically planned. iii) A relative shift of emphasis has occurred from the production of goods to the provision of human and technical services. iv) This has led to a change in the occupational structure, which is indicated by the growth in numbers and influence of a professional and technical class. And finally, v) the most senior of the service workers become the ruling class of the new society. They rule because they control theoretical knowledge and plan future development. Bell is rather optimistic about the growth of employment opportunities in the post-industrial society. According to his forecast, the service society will create a never-ending supply of new job opportunities in services aimed at fulfilling the new needs that more wealth generates.

By now, Bell's optimistic prognosis has turned largely sour. Jeremy Rifkin (1995) indicates that in the past, when new technologies have replaced workers in a given sector, new sectors have always emerged to absorb the displaced labourers. Today, however, all three of the traditional sectors of the economy - agriculture, manufacturing and service - are experiencing technological displacement, with the result that the white collar occupations that constitute the service sector are now themselves being automated and made redundant. 
The only new sector, says Rifkin, is the knowledge sector, made up of a small elite of entrepreneurs, scientists, technicians, computer programmers and consultants. While this sector is growing, it is not expected to absorb more than a fraction of the hundreds of millions who will be eliminated in the next several decades in the wake of revolutionary advances in the information and communication sciences (RIFKIN, 1995: xvii).

3) Flexible rationalisation of the workplace: Theorists of the French Regulation School like Aglietta, Boyer and Lipietz contend that by the mid-1970's the Fordist regime of capital accumulation became unsustainable (LASH and URRY, 1987; HARVEY, 1989; BOYER and SAILLARD, 2002). Due to overaccumulation, the fourth Kondratieff or long wave of economic growth swung down, and by 1973 the world-economy had entered into a serious crisis. The main problem with the Fordist model of mass production, which was organised around the conveyor belt, was rigidity. The mass production of standardised goods, the centralised nature of decision making and the simplification of the labour tasks, leading to a deskilled, unmotivated labour force, made it unable to accommodate rapidly to changing market demands. The postFordist model reverses those characteristics (CROOK, PAKULSKI and WATERS, 1992: 167-196; WEBSTER, 1995: 135-162). In order to adapt to a ceaseless change in market demand, it constantly designs new and diversified products. Driven by knowledge and information, it is essentially a post-industrial mode of production, which moves away from standardised mass-production of similar goods to small batch production of diversified commodities. This shift from an 'economies of scale' (producing large numbers of standardised products in order to finance high levels of capital investment) to an 'economies of scope' (producing the widest possible range of commodities) goes together with, and is made possible by, a radical flexibilisation of the organisation of production along the lines of the Japanese model ('Toyotism'). 
First of all, the assembly line disappears and is replaced by teamwork. The production process is divided into a number of stages, each organised around a team of workers. Workers are qualified, multi-skilled, and rotate from one task to another. As extreme specialisation of the worker which characterised Fordism is replaced by flexible specialisation, workers are reskilled so that they can adapt to a wide range of tasks yet have the capacity to produce an expandable range of highly specialised products.

Secondly, decision making is decentralised and the hierarchy is flattened. The centrally controlled, vertically integrated and bureaucratically organised structures of command are replaced by a horizontal flow of information between all of the elements of the network involved in the production process. As a result of the flattening of the traditional organisational pyramids, middle managers, which were responsible for co-ordinating the flows up and down the organisational ladder, become largely superfluous and are forced to join the growing ranks of the unemployed.

The extreme form of managerial decentralisation is reached when corporations vertically disintegrate and subcontract with outsiders for the provision of as many as possible of the company's requirements. Combined with the strategies of wage flexibility (individualisation of wages, uncoupled from corporatist agreements between the employers and the unions), labour flexibility (fixed-term contracts) and time flexibility (parttime work), this strategy of outsourcing fits well with the global corporate strategy of 'downsizing'. By increasing the competition for scarce jobs among the members of the reserve army, it pushes pressures on the wages and so increases the flexibility of the corporations to remain competitive in the global economy, but at the same time this strategy of 'flexploitation' (BOUERDIEU, 1998: 99) 'disorganises' capitalism to such an extent that the 800 million human beings who are actually unemployed or underemployed in the world might very well signal the definite end of a societal form which is based on work and the utopia of full employment (OFFE, 1985a: 129-150). 


\subsection{Political Globalisation}

As a result of the multiplication and intensification of economic, political and cultural linkages and technological interconnections across boundaries, the nation-state tends to loose the importance it once had. It is increasingly reduced to being one possible organisational form among others. Accordingly, the classic theory of the "nation-state society" (ALBROW, 1996: 118), which erroneously identifies nation-states and societies has to be discarded. Although the global processes should not be exaggerated to represent either a total eclipse of the nation-state or the simple emergence of an integrated world society, the processes of globalisation nevertheless seem to justify the abandonment of the implicit postulate of 'methodological nationalism', which characterises classic sociology, and to require a refocussing of the sociological project - away from society and the nation-state towards the emerging world society. Such a redirection of the sociological project involves a creative cooperation between the disciplines of sociology, international political economy and international relations. If international relations, understood as the international branch of the political sciences which traditionally focusses on the diplomatic relations between states, and international political economy, understood as the branch of international relations which is concerned with the analysis of the ways in which international politics shapes or is shaped by the global economy, can contribute to sociology by adding an international dimension to it, I like to think that sociology can for its part enrich the discipline of international relations thanks to its analysis of the dialectical interplay between action and structures and the importance it attaches to social movements in the transformation of social structures. This presupposes, however, that the nation-state is no longer considered as the unit of analysis but that international networks and linkages between people across boundaries are analysed as the basis of the emergence of transnational social movements which could challenge the actual drift of globalisation by calling for a radical overhaul of its underlying premises. In 
other words, in a sociological perspective of political globalisation, transnational social movements are considered as transformative forces which mediate between the local life-worlds and the global system. By internationally coordinating the moral pressure on the national political systems, by means of what Habermas calls 'transnational domestic politics' (HABERMAS, 1998a: 78), they call for the instauration of supranational bodies of governance, or appeal to the existing ones, to regulate, domesticate and ultimately reorient the process of globalisation in the post-materialist direction of a socially, politically, morally and ecologically justifiable democratic order of 'humane governance' (FALK, 1995). The point is not to establish a world government which would re-regulate the deregulated economies but to force the national governments to take into account the demands for humane governance which come from the transnational interconnected life-worlds in such a way that the social functions of the welfare state, which so far have been executed by the nation-states and which the processes of economic globalisation are undermining, can be guaranteed by supranational instances. Given that the European Union is not just a unified market but involves a political and a social project as well, it makes sense to project the idea of a democratically legitimated supranational welfare state as the end state of the process of European unification (BOURDIEU, 1998: 66-75, HABERMAS, 1998b: 134-156).

Nowadays, politics can no longer be conceived as an insulated national social activity. The traditional distinction between domestic and international politics becomes blurred and, eventually, it has to go. Accordingly, the state-centric assumptions of the traditional theory of international relations, which privileges the territorial sovereignty of the nation-state and takes the nation-state as the primary unit of analysis, have become under serious strain (ROSENAU, 1990). The reasons for this withering of state-centrism can be sketched out in the following argument (HELD, 1991: 205$209 ; 1995: 89-96)$. With the increase in global interconnectedness, the borders between states become permeable and states increasingly loose the capacity to generate policy instruments able to control 
the transactions of people, goods and services, technology, money and information within and beyond its borders. The power of the state is further reduced by the growth in scale and numbers of international and transnational actors and processes. Transnational corporations, for instance, are often larger and more powerful then national governments. Many of the traditional areas of state responsibility (such as defence, communications and economic management) must therefore be co-ordinated on an international or intergovernmental basis. Accordingly, states have been obliged to surrender their sovereignty within larger political units (e.g. EU, Asean), multilateral treaties (e.g. Nato, Opec) or international organisations (e.g. IMF, World Bank). The result has been the emergence of a system of global governance with its own policy development and administration, which redefines and further curtails the power of states. This provides the basis for the potential emergence of a regional supranational state (e.g. the EU) with coercive and legislative power. Although such a transnational government is more necessary than ever, if only to regulate the financial markets and control the transnational corporations, it does not exist yet. The financial crisis shows, however, that the prospects for the emergence of transnational government that would be able to regulate the markets and end the neo-liberal hegemony of corporations and financial markets, are rather dim. At the moment (2014), it is not even clear whether the European Union will be able to survive.

\subsection{Cultural Globalisation}

One does not have to be a historical materialist to see that the worldwide spread of capitalism necessarily affects the cultural superstructure. Mass culture has indeed become a commodity and nothing but a commodity. The cultural industries have only aim: to sell, and what sells best is lowbrow amusement. It is sufficient to switch on the TV at prime time to be convinced of that. In any case, the use value of the cultural products has become secondary; what counts is their exchange value and the accumulation of 
capital. In this regard cultural products are not significantly different from other commodities. According to Horkheimer and Adorno (1948), the very processes of production in the culture industry are modelled on Fordist factory production. Everything is standardised, streamlined, co-ordinated and planned to the last detail. All products are mediocre and look alike. But in order to hide the abstract identity of mass-produced cultural commodities, the culture industry tries to serially differentiate them by stamping them with an air of originality.

While Adorno and Horkheimer derive the homogenisation of cultural products from the 'commodification thesis of culture', Herbert Schiller (1969) embeds the commodification thesis in an analysis of the global political economy of the media and presents it in the form of 'the Americanisation thesis of culture'. The communication and information sectors are oligopolistic and to a large extend controlled by American conglomerates, which pursue their corporate strategies in a global arena. Schiller argues that the American system of broadcasting, which is thoroughly permeated by the commercial interests of the transnational media conglomerates, has served as a model for the development of broadcasting systems elsewhere in the world, especially in the Third World. Given the huge costs involved in the domestic production, American TV programmes have been massively imported in the developing countries. The result of this 'cultural dumping' is a 'global electronic invasion' which massively infuses the culture-ideology of productivism and consumerism in indigenous cultures and puts them so to speak under an 'electronic siege' which seriously threatens the cultural integrity of weak societies. By literally colonising the local life-worlds with Western cultural products ("Californication"), the global system of communications, which is privately owned and concentrated in the hands of a few transnational conglomerates, imposes uniform standards of media and consumerist models of life, undermining the local cultures and leading thus to the Americanisation of indigenous cultures. 
However convincing the arguments of the neo-Marxist may sound, they are nevertheless one-sided, and doubly so. Firstly, they do not sufficiently take into account the extent to which the socio-economic move to post-industrial Fordism is correlated with a cultural move to post-modernism (i), and secondly, they fail to consider the local reception of global culture and do not see that as soon as Western cultures are brought into new societies they tend to become indigenised in one or another way (ii).

(i) Contemporary mass culture is indeed more and more commodified, but that does not mean that it is standardised and homogenised. To the contrary, commodification leads to diversification and heterogenisation. Today's mass culture is pluralist, heterogeneous, fragmented and diversified - or postmodernist, to say it in one word which summarises it all. In so far as the post-modernisation of culture is linked to its commodification, post-modernism and its 'figural regime of signification' has itself to be analysed and understood in the framework of economic globalisation and the correlated shift from the Fordist to the post-Fordist regime of accumulation (LASH, 1990: 37-52, 172-198).

Lash and Urry have demonstrated that the cultural industries were 'post-Fordist avant la lettre' (LASH and URRY, 1994: 123). Even in the heyday of Fordism, the cultural industries were driven by innovation and design intensive. Confronted with a crisis of overaccumulation, the other sectors of the industry have followed the post-Fordist track of the culture industries since the seventies. What is increasingly being produced and consumed nowadays are not material objects but semiotic objects or signs. The design of consumer products becomes more and more important. As a result, objects are increasingly aestheticised and emptied out of their material content. The aesthetic form trumps the material content. Use value becomes secondary, and at the end, everything happens as if it is now the exchange value which induces the use-value. Even more, according to Baudrillard, the exchange value simply absorbs the use value, becomes self- 
referential and turns into a simulacrum, that is into a copy without an original (BAUDRILLARD, 1972; 1985). Although Baudrillard's influential theory of 'hyperreality' playfully, and at times, cynically exaggerates the extent of the dematerialization of reality, there can be no doubt about the fact that the 'spectacularisation' (Debord) of commodities indeed characterises contemporary consumer culture. In this sense, Jameson is right when he defines post-modernism as the 'cultural logic of late capitalism' (JAMESON, 1991).

(ii) The thesis of American cultural imperialism is problematic. Not so much because competing media centres have emerged in Europe, Latin America and Asia, but because it stays at the global level of a political economical analysis of the transnational media conglomerates and fails to take into account the local processes of interpretation of the globally diffused media messages. It assumes that Dallas and Dynasty, for instance, are everywhere interpreted in the same way and does not see that cultural messages which directly emanate from 'the USA' are differentially received. Analysing the dialectal hermeneutics of the global diffusion and localised reception of cultural messages, John Thompson rightly stresses that the appropriation of media products is always a localised phenomenon, in the sense that it always involves specific individuals who are situated in particular social-historical contexts, and who draw on the resources available to them in order to make sense of media messages and incorporate them into their lives' (THOMPSON, 1995: 174). The globalisation and the localisation of cultural messages are thus not exclusive. The trend towards homogenisation and heterogenisation coexist; they are complementary and interpenetrative. Globalisation does not mean delocalisation but presupposes relocalisation in the same way as the homogenisation of culture goes hand in hand with its indigenisation. To overcome the opposition between globalisation and localisation, homogenisation and heterogenisation, Robert Robertson has coined the concept of 'glocalization', understood as the global institutionalisation and construction of local particularisms (ROBERTSON, 1995). 
Nowadays, even the multinationals take the local characteristics into account in their global marketing strategies. Goods and services are tailored and advertised in such a way that they tune in with the local traditions. And the local products are themselves increasingly marketed and exported to the West. Diversity sells. Western brands are exported to the Third World and exotic products from the Third World are imported in the West. The impact of non-western cultures on the West should not be underestimated. It is enough to think about phenomena like 'Thai boxing by Moroccan girls in Amsterdam, Asian rap in London, Irish bagels, Chinese tacos and Mardi Gras Indians in the Unites States' (NEDERVEEN PIETERSE, 1995: 53) to underscore the point. As a result of the bi-directionality of transnational flows, the opposition between the cultural centre and the periphery tends to loose its usefulness.

In any case, culture should no longer be conceived as territorially bounded, stemming from a socialisation process that is localised. The lessons from the cultural and postcolonial studies movement (Spivak, Bhabha, Gillroy, Hall, etc.) should be heard, and endorsed: culture is plural, cultures evolve, are interconnected, interpenetrate and mix. The relativist vision of cultures as a mosaic of well defined bounded units of equal value has to be dynamised and dialecticised into the vision of a leaky mosaic in which cultures run over their edges and flow into one another' (FRIEDMAN, 1995: 85). Cultures mix and interpenetrate. A 'hybridisation' and 'creolisation' of culture ensues which is not simply 'multi-cultural' but rather 'intercultural'. In a world where the local and the global are intertwined, culture becomes 'glocal' as well. As local cultures are interconnected with the global, they become 'subcultures, as it were, within the wider whole' (HANNERZ, 1990: 237). ${ }^{4}$ As a result

\footnotetext{
${ }^{4}$ This does not mean that globalisation might not lead to the strengthening of local cultures and identities. Indeed, the recent rise of virulent micronationalisms and religious fundamentalisms points in that direction, but those attempts to strengthen local cultures and particularistic identities should themselves be interpreted in terms of a resistance to globalisation which is not unaffected by it (HALL, 1992: 291-314).
} 
of this intercultural hybridisation, imagination takes on a global flight as well. Individuals, and especially young individuals who live in an imaginary global world, consider a plurality of variations of 'possible lives' (APPADURAI, 1998).

\section{Reflexive modernisation and Individualisation}

\subsection{Reflexive modernisation}

So far I have mainly stressed the structural determinants of the global economic, political and cultural changes which societies worldwide are undergoing. Although the political and the cultural systems follow their own laws and cannot simply be reduced to a mere epiphenomenon of the economic system, it is clear that the development of the former is influenced by the development of the latter. From this perspective, even the emergence of a global culture, which is created as we have seen through the increasing interconnectedness of varied local cultures, cannot be disconnected from the processes of economic globalisation. However, if we don't want to end up with a one-dimensional picture in which global structures are seen to overdetermine local actions, the structural perspective of a political economy of flows has to be augmented and corrected by a more voluntaristic perspective which stresses the increasing power of individuals vis-à-vis social structures. Even more, if we want to conceive the possibility of a counterhegemonic challenge of neo-liberal capitalism, we have to reverse the picture and try to show that global structures are increasingly dependent on local actions and that the coordination of local actions, which are reflexively directed against the global system, can possibly lead to its transformation. In order to accomplish such a reversal, I will draw on the theory of reflexive modernisation as 
Anthony Giddens, Ulrich Beck and Scott Lash have developed it (BECK, GIDDENS and LASH, 1994) ${ }^{5}$.

The concept of 'reflexive modernisation' was first introduced by Ulrich Beck in his influential book on the risk society (BECK, 1986, part III). In this book, which appeared in the wake of the Chernobyl disaster and which has exercised a large influence not only in the coteries of German social theory but in the larger German public sphere as well, Beck gives a critical-ecological twist to Daniel Bell's celebration of the advent of the post-industrial society. The catchword 'risk society' is intended as an epochal construct which refers to a developmental phase of modern society in which ecological hazards and risks become so prominent that they alter, and eventually undermine, the modern arrangement of industrial capitalist society that has generated them. As the 'social production of wealth' is systematically linked in the risk society to the 'social production of risks', the old politics of the distribution of 'goods' (income, jobs, social security) of the industrial society gives way to a new politics of the distribution of 'bads' (hazards and risks) (BECK, 1986: 25-27). As a result, the risks, which are induced and introduced by modernisation itself, become one of the main themes of private and public discussions. Compared to the dangers of industrial society - they just happen -, the risks of the risk society are socially manufactured and predicated on the awareness of a potential threat, whose occurrence can be predicted and whose likelihood can be statistically predicted, even if one can no longer be insured against it. Indeed, nowadays, ecological risks are catastrophic in their potential. The environmental dangers posed by large-scale nuclear or chemical accidents and genetic engineering entail the possibility of the self-annihilation of the human species. Moreover, modern risks are not spatially limited in

\footnotetext{
${ }^{5}$ Beck's theory of reflexive modernisation is a general theory of modernity that contains and integrates three theoretical projects under a single umbrella: the theory of the risk society, the theory of individualisation and the theory of cosmopolitanism, which was worked out later in a trilogy and falls beyond the remit of this article.
} 
their effects but threaten entire societies and are potentially global in their reach. Like toxic clouds, radioactivity transcends spatial borders and makes no discrimination between classes. Risks, however, escape sensory perception and exceed our imaginative capabilities. It is the scientists who detect risks, it is they who define the thresholds of acceptable and thus ipso facto accepted risks, and it is they who propose remedial solutions. Risks are thus discursively mediated and socially constructed by the scientific experts. And as the experts are increasingly contested by counter experts, for instance those of Greenpeace or Friends of the Earth, the political implications of the scientific management of risks become visible, not only to the experts themselves but also to the larger public.

At this point, it becomes clear that Beck's sociology of the risk society is basically a political sociology of knowledge which aims to update the German debate of the sixties about technocracy by giving it a post-modernist twist. Not that Beck is a post-modernist. He is too much a Habermasian for that, as can be glanced from his will to reflexively continue the project of modernity and his call for an 'ecological Enlightenment' (BECK, 1991: 117-139). But he picks up the arguments about epistemological insecurity, the absence of foundations of knowledge and the deconstruction of logocentrism, and transposes them from the abstract level of post-modern social theory to everyday life. People have become increasingly sceptical about the promises of scientific and technological progress. They do not hesitate to openly contest the scientific experts. In any case, they no longer take their expertise at face value. As a result of this move from a 'critical theory of society' to a 'theory of social self critique' (BECK, 1993: 54), the pessimism which surrounded the old debate about technocracy can now be replaced by cautious political optimism. Now that the dangers of industrial society begin to dominate public, political and private debates the project of technocracy is publicly unmasked as a political project and the 'relations of definition', which take the place of the relations of production of industrial society, are revealed for what they really are, namely 'relations of power' which scientifically legitimatise 
the potentially disastrous politics of the risk society (BECK, 1988: 211-216, 220-226). The enemy is thus still the same - technocracy but now that he has so to speak become public, he has to publicly legitimise his technocratic project as a political project. And given that this political project potentially leads to catastrophes, it is no longer accepted at face value but is more and more contested by the population at large, with the result that politics and morality are gaining primacy over scientific reasoning.

Although Risk Society is mainly concerned with the ecological consequences of industrial society and has not much to say about the social consequences of economic globalisation, his arguments can easily be extended to it. Indeed, it could be argued that in the same way as the population at large has become sceptical about the scientific experts, it has also started to question the expertise of neo-classical economists who scientifically legitimise the neo-liberal politics of financialisation that led to a global crisis. The result of popular challenges of neo-liberalism is a massive repoliticisation of the economy which denaturalises the laws of the market and shows that in the same way as the scientific experts are blind to ecological risks of the industrial cult of productivity, the economists are blind to the social risks of financial capitalism.

According to Beck, the ecological crisis is not just a crisis of the environment but a genuine social crisis, which reveals the cracks in the foundations of industrial capitalist society. At the end of the twentieth century, industrialisation and formal rationalisation have become problematic. Beck argues that the advance of industrial modernisation ends up by creatively undermining modernisation itself, leading thus to the advent of a'second modernity' in which the damaging consequences of rampant industrialism become a topic of public concern. Reversing the doom scenario of the Frankfurt School's Dialectic of the Enlightenment, he argues that the successes of industrial capitalism do not lead to a hopeless integration of all possible resistance to the status quo, but that they unleash a new kind of crisis of legitimation in which ecological crises now take over the role which Habermas once ascribed to the economic crises of late capitalism (HABERMAS, 1975). Indeed, confronted 
with the BSE crisis, global warming and the possibility of a nuclear winter, people become increasingly sceptical about the promises of scientific progress as such. The technocratic ideology, which represents the technological counterpart of the economic doctrine of laissez-faire (FREITAG, 1989: 62), looses its credibility. As a result of this challenging of the authority of science and technology, the 'technological veil' (Marcuse), which fetishistically misrepresents political decisions as technical decisions, is torn apart. People become conscious of the fact that the ecological dangers are socially manufactured and that even natural catastrophes are the result of men's intervention in and social tinkering with nature. Confronted with the consequences of the politics of industrialisation, industrial society becomes reflexive, which is to say that it becomes a theme and a problem for itself.

This self-thematisation and self-problematisation of industrial society is at the centre of Beck's theory of reflexive modernisation (BECK, 1991, 180-194; 1993: 35-69; 1995: 11-30; BECK, GIDDENS and LASH, 1994:1-13). The main idea of this theory is that the pursuit of industrial modernity undermines the systemic foundations of industrial modernity itself and leads to a 'modernisation of modernisation' which opens up the way to an alternative and ecologically enlightened modernity. This is the case because the accumulation of perverse consequences of industrial modernisation produces systemic threats that cannot be dealt with and assimilated in the system of industrial society, and eventually, as people become increasingly aware of it, it destroys it. Once more Beck reverses the industrial fatalism of the Frankfurt School: more formal rationalisation does not lead to an increase of reification, but eventually to its decrease. Two steps can be distinguished in this process of dereification. Firstly, the autonomous logic of the reified system unintentionally but systematically creates consequences which threaten the survival of the system and which cannot be resolved within the system (e.g. solving the ecological crisis which is created by scientific and technological control by a scientific and technological control of its effects or solving the problem of mass employment while pursuing the neo-liberal policy of globalisation). 
Secondly, confronted with the risk of self-annihilation of the system, people become aware of the systemic causes of this risk, ring the alarm bell, submit the system to a systematic critique and call for fundamental political changes of the system. And as the crisis of the system passes from the system to the life-world, the system itself becomes increasingly dependent on the legitimations of the life-world. The 'iron cage of modernity' breaks open. Actors do not simply reproduce the structures, but call for their transformation. The classic dialectic of actions and structure is loosened, if not reversed. The structures themselves become the object of social processes of debate and change. Confronted with the social and ecological effects of a technocratically implemented policy of global economic growth, people become suspicious of the political system as such, withdraw from it, and retreat to the lifeworld, where they develop alternative forms of life which are not without possible political consequences for the larger system.

\subsection{Reflexive Individualisation}

The theory of reflexive modernisation does not replace Habermas's morally inspired analysis of the legitimation crisis of late capitalism (HABERMAS, 1975), but supplements it with an ecological dimension. The 'basic contradiction' between the operation of late capitalism and the logic of democracy remains, but it can no longer be justified from the point of view of postconventional morality. Individuals no longer accept the social and ecological price which the members of the industrial capitalist societies pay for the policy of economic growth and call for a democratic, yet radical transformation of their foundations. Both theories basically formulate a theory of the political effects of a morally induced legitimation deficit which industrial capitalist societies face when they are judged according to the postmaterialist criteria of post-conventional morality. Sociologically speaking, they both presuppose that individuals are set free from social structures to such an extent that they are able to distance themselves reflexively from the traditions and conventional modes 
of thought and judgement in which they have been socialised to critically think for themselves. In other words, 'reflexive modernisation' presupposes 'reflexive individualisation'.

The individualisation thesis, as it has been advanced by Beck (BECK, 1986: 205-219; 1995: 31-41) and Giddens (GIDDENS, 1991), advances the (Simmelian) claim that under the conditions of high modernity (young middle class) individuals are increasingly set free ('freigesetzt') both from cultural constraints, such as religion, tradition, conventional morality and the unconditional belief in the validity of science, and structural constraints, such as class, status, nation, gender and the nuclear family. ${ }^{6}$ As the binding force of inherited forms of social life is dissolved, individuals can reflect on the implications of cultural and structural processes and thereby choose which of them they become involved in. The result, of course, is that self-identity becomes a reflexively organised endeavour. What was once inherited by tradition and taken for granted requires now a conscious decision by the individual. Identity is no longer ascribed but achieved. As Peter Berger says: "What previously was fate now becomes a set of choices. Or: destiny is transformed into decision" (BERGER, 1979: 16). Indeed, confronted with a plurality of life-worlds and lifestyles, individuals must now produce, stage and cobble together their biographies themselves. Biography thus becomes, as Berger said well before Beck and Giddens, a "designed project". This design includes identity. "The individual not only plans what he will do but also plans what he will be" (BERGER, BERGER and KELLNER, 1974: 74).

The core assumption of the individualisation thesis is that as (young middle class), individuals are set free from structural

\footnotetext{
${ }^{6}$ For documentation on and discussion of the individualisation thesis, see also Beck and Beck-Gernsheim, 1994 and Heelas, Lash and Morris, 1996. Beck and Giddens present the process of individualisation as process which affects everyone in late modernity. In the last part of this article, I will analyse the material conditions of reflexivity and restrict the scope of the individualisation thesis to the young middle classes.
} 
and cultural constraints they have to reflexively design their own biographies. Reformulated in terms of the classic opposition between agency and structure (and culture), which is now displaced from a methodological to a socio-historical issue, we could say that individualisation implies that agency is set free from structure (and culture). However, individualisation is a highly dialectical process in so far as it is due to structural and cultural constraints that agency frees itself from structural and cultural constraints. Indeed, processes of reflexive individualisation do not occur in a social vacuum but are the consequence of a radical transformation of (i) the cultural conditions (detraditionalisation, cultural globalisation and scientificisation of conduct) and (ii) the structural conditions (the labour market) of late modernity.

(i) Cultural conditions: Our world is a post-traditional world in which the Parsonsian model of a smooth and well integrated complementarity between the social, the cultural and the personality systems has been dissolved by the 'institutionalisation of reflexivity' (SCHELSKY, 1965). The elements of the cultural system are no longer simply, almost automatically, introjected but, as Schelsky had already noted at the end of the fifties, cultural traditions become reflexive and become the subject of discussion. And as they are submitted to discussion, their validity is necessarily weakened, because traditions only retain their binding force if their pretensions are not questioned but accepted at face value.

Moreover, in a global world, local cultural traditions are no longer insulated from other cultural traditions, but they start to mix and to interpenetrate. And as they do so, the local cultures necessarily loose their binding force and become optional. One can live like a Rastafari in São Paulo and like a Paulista in Ethiopia. The global diffusion of the mass media and the pluralisation of lifestyles they celebrate only increases the optional character of cultural models.

Add to this the fact that we are increasingly dependent on abstract or expert systems of knowledge, that our every day actions increasingly incorporate expert knowledge of the most different sorts and that this expert knowledge is essentially plural 
and fallible, contestable and contested, and it becomes clear that the radical doubt which characterises post-modern theory now permeates the life-world as well.

The combined result of detraditionalisation, cultural globalisation and the scientificisation of everyday life is that individuals are confronted with a wide range of available models of conduct and that they have no other choice but to choose for themselves which of them they are going to follow. And given that there are no guarantees that the choice is the right one, this choice is necessarily a risky one.

(ii) Structural conditions: The capitalist labour market is and remains the central institution of contemporary societies. According to Beck, it is also the main engine which drives the process of the reflexive individualisation of life-forms forwards (BECK, 1986: 115-160; BECK and BECK-GERNSHEIM, 1994: 43-60). This is the case in so far as one's chances on the labour market are systematically linked to prolonged education, frequent mobility and increased competition, each of which brings about individualisation in its own way. Education replaces traditional modes of thinking by more universalistic and reflexive ones; social and geographical mobility dissolves the primary bonds of sociability and forces one to interpret one's own destiny as a personal destiny; and competition for scarce positions leads to isolation from one's equals. Moreover, the processes of economic globalisation have induced a radical flexibilisation of the labour market with massive unemployment, a spectacular rise of fixedterm and widespread economic insecurity as a result. Although this economic insecurity is systemically induced by the processes of economic globalisation, it is interpreted by the individuals as a personal failure. This, together with the fact that the importance of work as a source of self-identity has declined, explains why a sense of class consciousness and class solidarity no longer prevails.

This dissolution of collective consciousness and solidarity cannot be compensated, however, by a retreat to the traditional family. This road is barred as well, not only because the entrance of women in the labour market is linked to the same processes 
of individualisation, but also because the emancipation of women has largely dissolved the traditional institution of the nuclear family. Now that women earn their own income, they are no longer dependent on their husband and can experiment with non traditional forms of intimate relations, such as cohabitation, livingapart-together, bi- and homosexual relations, single motherhood etc. Confronted with a plurality of post-conventional alternatives to the nuclear family, individuals are thus forced to choose for themselves which option they will pursue (BECK and BECKGERNSHEIM, 1990).

It has often been assumed that this liberation of the (young middle class) individuals from structural and cultural constraints leads to an atomisation of society where anomie is rife and autonomy impossible. However, against both the critics on the left, who argue that individuals are only liberated from society to be recuperated by society and manipulated by the market, and the right, who lament about the moral decline of the West, without indicting the free market, I would like to defend the heuristic claim that anomie and autonomy do not necessarily exclude each other, but can and actually do include each other. I do not deny that individualisation and anomie can go together, but anomie can only be interpreted as a serious threat to the individual and society if it is seen against the backdrop of the well integrated nomic order of the past. However, in a post-traditional society this nomic order does no longer exist. People have to choose for themselves which models of conduct they will follow. This is not without risk for the individuals concerned or for society at large, but there are empirical indications that the demise of traditional values does not lead to nihilism but rather to an increased emphasis on the quality of life and democratic political institutions. Indeed, Inglehart's 'theory of intergenerational value change' (INGLEHART, 1977) has now been empirically confirmed. The historically unprecedented degree of economic security experienced by the post-war generation in most industrial societies has led to a gradual shift from 'materialist values' (emphasising economic and physical security above all) toward 'post-materialist priorities' (emphasising self-expression, 
autonomy and the quality of life). Nowadays, materialists and post-materialist are about equally numerous, whereas in 1970 materialists still outnumbered post-materialists by nearly four to one. Inglehart's recent analysis of the World Value Surveys, which provide data from 60.000 respondents of 43 societies representing $70 \%$ of the world population, consistently confirms his thesis that a 'post-modernist' shift in general and a 'post-materialist' one in particular have occurred in the last 35 years, especially among the younger cohorts of Western societies (INGLEHART, 2008). The confidence in religious, political and scientific authority is declining; yet at the same time individuals bring a growing mass desire for participation and self-expression. In political participation, the emphasis is shifting from voting for traditional parties to more active and issue-specific forms of mass participation. In economic behaviour, emphasis is shifting from maximising one's job income toward a growing insistence on interesting and meaningful work. In sexual norms and family life, traditional norms have been replaced by greater flexibility for individual choice in sexual behaviour with a particularly dramatic increase in the acceptance of sexual behaviour outside marriage and of homosexuality. In the realm of ultimate values, the declining confidence in churches is accompanied by an increase in spiritual concerns with the meaning and purpose of life. These data thus convincingly show that we are not so much witnessing a loss of values as a conflict between materialist and post-materialist values.

\section{Youth and Social Change in Late Modernity}

\subsection{Youth - Sociologically Defined}

The study of youth provides an ideal opportunity to examine the relevance of the theories of social change in late modernity. If the processes of globalisation, reflexive modernisation and individualisation have fundamentally changed the contours of modern societies, as Giddens and Beck claim, we would expect 
to find strong evidence of these changes among young people. And indeed we do. If we define youth not in biological terms as a physiological phase, commencing in puberty and ending with sexual maturity, or in psychological terms as a phase of personal life extending through the different phases of adolescence and post-adolescence, but as a social category, framed by particular institutions, especially education, the labour market and the family, and social acts, such as getting educated, leaving home, finding a job and forming a family (FORNÄS, 1995: 3), we can conceive of youth as a relatively extended phase of transition between childhood and adulthood which is marked by three status transitions (GALLAND, 1995), namely the professional transition (leaving full-time education and entering the labour market), the domestic transition (attaining relative independence from the family of origin) and the housing transition (moving away from the parental home).

Up until the 1970's, the life course of young people was highly structured along the lines of class and gender and relatively standardised. For young working class males the thresholds of the status transitions tended to coincide in such a way that completion of studies was usually closely followed by commencement of working life, which in turn led to leaving home and living as a couple. Whereas middle class males might put off the thresholds that mark the status transitions indefinitely, keep their options open and change their path as they went go along, women might skip the occupational stage, leave their parent's home to marry and move in with their husband. In the last decades, structural changes in society have led to a destructuration of the labour market and cultural changes to a detraditionalisation of the patterns of behaviour. Those changes have affected the relationships of young people with family and friends, their experience in education and labour, and their ability to become established as young adults to such an extent that transitions have been significantly extended, if not postponed altogether, and the life course destandardised and individualised. Metaphorically, the standard biography of yore, described in terms of status transitions, can be viewed in terms of 
railway journeys (FURLONG and CARTMEL, 1997: 6-7). Within the school, young people join trains which are bound for different destinations. The trains they board are determined by social class, gender, ethnicity and educational achievement. Once the train journey has begun, opportunities to switch destinations are rather limited. The changes in the last twenty years, which have led to a replacement of the standard biography by a reflexively orchestrated and individualised 'choice biography' can best be described in terms of the wholesale closure of the railways. With the absence of trains, the journey is now undertaken by car, giving thus the drivers the opportunity to select their route from a vast array of alternatives. Given the flexibilisation of the labour market, one is tempted to add with Frank Coffield that the life course of a significant number of young people who cannot afford a car and have to rely on privatised public transport now also consists of 'long periods waiting in the rain at the bus stop for transport of any kind to arrive' (COFFIELD, 1997:45).

The destandardisation and individualisation of the life course of young people does confirm Beck and Giddens's indvidualisation thesis. Yet, at the same time, the individualisation thesis tends to obscure that the process of neo-liberal globalisation has seriously affected the life chances of people and that the social relations of inequality have remained stable over the years. Although the collective material foundations of social life have become more obscure, they nevertheless continue to provide powerful frameworks which directly constrain the life chances and indirectly the lifestyles of the majority of the population. In theory, everyone has the chance to reflect on his or her life and to freely choose his or her lifestyles and life course; in practice, however, reflexivity remains largely a prerogative of the young white male members of the middle classes. As Bauman says: "It is the individual responsibility for choice that is equally distributed, not the individually owned means to act on the responsibility" (BAUMAN, 1997: 196).

The problem with Beck and Giddens is that they largely ignore the class-, race-, gender- and age bases of reflexivity. The 
kinds of reflexive practices heralded by them presuppose that basic material interests are satisfied so that individuals can distance themselves from their immediate needs and the sensuous world to reflect on social structures. In this way, the social determination of social structures is broken and individuals can decide which ones to act on, which to ignore, which to oppose, and so on. The adoption of a Bourdieusian perspective (BOURDIEU, 1979) allows us see that his capacity to stand outside relations and to reflect on them is not universal but part of the class habitus which is associated with the academic and intellectual middle classes. Moreover, in so far as the relation between the satisfaction of material needs and the capacity of reflection is not an immediate one but reflects the conditions that prevailed during the socialisation process, we could argue with Inglehart (1971) that the processes of reflexive individualisation are characteristic not of all ages but mainly of the younger cohorts. Using once more the transport metaphor, we could summarise the discussion of the individualisation thesis by saying that the private car has indeed replaced public transport, but that class, race and gender still significantly determine the trajectory of the life course of young people. What Beck and Giddens thus fail to realise is that 'the type of the car (e.g. a Porsche or a Skoda) which young people have been allocated at the start of the journey remains the most significant predictor of the ultimate outcome' (FURLONG and CARTMEL, 1997: 7).

Looking in more detail at the 'stuctured destructuration' of the status transitions that define youth as a social category, we can see that the deferral of the changes in the life course which intervened in Europe in the last decades are primarily induced by the global economic shift towards a post-industrial flexibly organised labour market (CAVALLI and GALLAND, 1995, FURLONG and CARTMEL, 1997). With a sharp decline in demand for unqualified minimum-aged school leavers, young people from all social classes are now remaining in full-time education until a later age. High education is becoming a mass experience rather than the preserve of a small elite. These changes have led to a protraction and diversification of transitions from school to 
work. Yet, in so far as labour market positions can still be fairly accurately predicted on the basis of social class (via educational performance), those transitions remain highly stratified. New forms of 'flexploitation' have reduced job security and many of the least qualified young people remain trapped on the labour market periphery and are vulnerable to periodic unemployment. The crises and the unprecedented high levels of unemployment (up to half of the youngsters between 16 and 24 are unemployed in Greece, Portugal and Spain) have only accentuated the tendencies. In spite of the economic recovery, the situation is even worse in the United States (WACQUANT, 2009). There's no safety net, and the marginalisation and criminalisation of the young black 'underclass' has advanced to such a deplorable level that there are actually more young blacks in prison than in higher education. Reduced to the role of an 'oversized police precinct' (BAUMAN, 1998:120), the state does no longer aim to re-educate the young delinquents. They are 'dumped' and 'stocked' en masse in privatised prisons.

Along with the protraction of the school to work transition, there has been an extension to the period in which young people remain in a state of semi-dependency. In Southern Europe, most of the young individuals tend to continue to live with their parents till they hit their thirties and marry swiftly after leaving the parental home. In Northern Europe, young people tend to leave the parental home earlier and are increasingly likely to spend time living in intermediate households before they set up their own household. In any case, the domestic transition is not necessarily followed by the housing transition. This tendency to protract and defer the domestic and housing transitions, which is notable across the classes and genders, is part of a general process of the 'gentrification' of lifestyles and life courses.

Incorporating elements of working class cultures in middle class ones and vice versa, the class divisions are culturally blurred. However, even if the distribution of lifestyles has become more democratic, the distribution of the life chances has remained as hierarchical as ever. 
The distinction between life chances, which are directly determined by economic capital and indirectly by culture, and lifestyles, which are indirectly determined by money and directly by cultural capital, allows us now to specify the range of the individualisation thesis and to clear up the paradox of late modernity. In spite of the economic downshift, there's no reason to assume that capitalism is going to enter into its final decline. It may well take another 20 to 30 years for a new, stable regime of accumulation to emerge, but everything indicates that capitalism is there to stay. The 'causality of the probable', which delimits the possible social trajectory of a given individual and determines his or her life chances, remains largely overdetermined by class position. Yet, subjectively, class consciousness has waned, if not disappeared altogether. Rather than blaming the system or look for collective solutions, individuals blame themselves for their insecurities and seek solutions on an individual basis. In this sense, late capitalism equals capitalism without Marxism. The disappearance of class consciousness is enhanced and stimulated by commodification of culture and the commercialisation of lifestyles, which systematically blur all social divisions (class, gender and ethnicity), masking the privileges of the young people from the middle classes and creating thus the pseudo-Nietzschean illusion that everyone can be what he or she is.

\subsection{New Social Movements}

Notwithstanding the persistence of unequal social relations, the old politics of the labour movement are now completely out of synch with reality. The revolutionary overthrow of capitalism may still appear on pamphlets of the extreme left, it is no longer on the agenda. Thanks to the neo-corporatist arrangement between the state, the employers and the unions, the class conflict has progressively been institutionalised. Since the seventies, the neo-corporatist arrangement has come under serious strain. If economic and political globalisation has eroded the traditional powers of the state from above, the anti-corporatist mood of the 
post-materialists and the neo-liberal backlash have attacked the state from below (OFFE, 1985b: 817-825; CROOK, PAKULSKI and WATERS, 1992: 83-105). The breakdown of the neo-corporatist arrangement and the post-materialist value-shift have made the paradigm of traditional politics increasingly inadequate to understand the political complexion of late modernity. Unions and political parties are still important of course, but outside the corporatist system new social movements (NSMs), such as the feminist, ecopax, and youth movements, have emerged which challenge the existing system and compete with the power elites for the shaping power of the political. Although those NSMs are extra-parliamentary or extra-institutional forces that emanate from the life-world, they are still political forces in so far as they aim to redirect and transform not only the political system as such, but the larger economic and social system as well. As long as we have not overhauled the old paradigm of politics, their political significance will inevitably escape us, as we will go on looking for the political "in the wrong place, on the wrong floors and on the wrong pages of the newspapers (BECK, GIDDENS and LASH, 1994: 18).

If we now compare the elite-directed politics of the workingclass or labour movement, which was the paradigmatic 'old' social movement, with the elite-challenging politics of the NSMs, we can notice important differences with regard to the location (i), the class determination (ii), the aims (iii) and the organisation (iv) of political processes and movements (COHEN, 1985; CALHOUM, 1993; MELUCCI, 1996)

(i) The politics of the NSMs are 'movementist' rather then 'statist' in orientation. Located within civil society, they tend to bypass the state and are little concerned to challenge the state directly. Unlike the old labour movement, which was utopian in orientation and sought to remake the whole of society through overcoming existing relations of production, NSMs are predominantly defensive in orientation. They accept the democratic state and the market economy and do not try to abolish them, but attempt to domesticate and to transform them democratically in such a way that money and power do not undermine the 
communicative, expressive and emotional infrastructures of the life-world.

(ii) Actors involved in the NSMs do not view themselves in terms of a socio-economic class. Given that the processes of reflexive individualisation have weakened, if not dissolved, the collective class consciousness and solidarity, political economic identities have lost their salience and are being replaced by a mixture of ascriptive identities (like race, age or gender) and expressive identities (like sexual orientation or identification with various lifestyle communities). In this sense, Dubet is right when he states that social movements are 'movements of individuals' (DUBET, 1994: 186), but he forgets to specify that the actors primarily come from the younger segments of the 'new middle classes'. This is not because the youth or the middle-classes experience a class- or agespecific powerlessness, but because they identify most with the post-materialist values which the NSMs appeal to (EDER, 1993: 158-184).

(iii) In contrast to older social movements, the NSMs are primarily social or cultural in nature and only secondarily, if at all, political. Their concern is less with political power than with the cultural sphere, their focus being not on material interests but on moral values and expressive life-styles. Criticising the productivist model of the working class movement, they bring forward a variety of other issues which are grounded in aspects of personal life (sexuality, ethnicity, ecology), are concerned with the democratisation of structures of everyday life, or focus on the expressive forms of communication and the defence of the integrity of the life-world. They aim to bring about social change through changing values, developing new life-styles and challenging the identities of social actors.

(iv) The NSMs abandon the organisational mode of the labour movement. Instead of forming unions or political parties of the socialist, social democratic or communist type, they focus on grass-roots politics and insist that the organisational forms and styles of movement practice must exemplify the values the movement seeks to promulgate. Consequently, many NSM's 
|161|

are committed to direct democracy, a non-hierarchical structure and informal networks. Organised around specific issues, membership of the movement is shifting and numbers fluctuate, with participants joining and then disengaging as the political context and their personal circumstances change. In this sense, NSM's represent "hidden networks" of informal relations which can remain latent to "become visible whenever collective actors confront or come into conflict with a public policy" (MELUCCI, 1989: 70). Circumventing the routines of election and lobbying, they take recourse to direct action and novel tactics.

Towards the end of the millennium, new forms of protest have emerged on the scene and taken on a global facture. Spawned by the revelation of hidden project of the WTO to radically liberalise international trade, the "Battle of Seattle" of 1999 marked the emergence of the anti-globalization movement and opened up a new chapter in the history of the new social movements. Distracted by the sequels of 9/11, the Global Justice Movement slowly petered out at the same time as it got institutionalised in the World Social Forum. What remained, however, were a myriad of coalition movements, direct action mobilisations, massive use of social media and new tactics of protest (such as the infamous black block tactic). The Arab Spring, Occupy in the USA, Los indignados in Spain and the protests in Brazil are so many instances of a moving field of social forces. Worldwide, contentious politics has entered into a new phase. The times are ripe for new NSM's.

\subsection{Youth - Culturally Defined}

Having outlined the main characteristics of the NSMs, I would now like to conclude this article by some considerations on the importance of the youth and of youthfulness in those movements. Following Dilthey and especially Mannheim (MANNHEIM, 1964), I would like to present a conflictual and cultural definition of youth, which ties youth to the formative influences of the Zeitgeist to which one is responsive, and to insist that the conflict of generations can be as influential as the class 
conflict. However, to take the reflexivity of late modernity into account, I think that we should not so much focus on the influence of the actual Zeitgeist of one's adolescent years, as Mannheim does, as on the actual influence of the life-forms and life-styles of the youth to which one is responsive. Youth is linked to a certain openness of the mind which expresses itself through the fact that the individual consciously and selectively orients him or herself to the alternative life-styles of the youngest cohorts. In so far as youthfulness goes together with a self-evident refusal to blindly follow the traditional injunctions and a wish to continually stay tuned to and experiment with the possibility of change, one can be still be young at 40 in the same way as one can be old at 25 . What matters is that one sympathises with and orients oneself to the experimental fractions of the young cohorts, not that one biologically belongs to them.

Under conditions of reflexive individualisation, individuals are set free from the traditional binding norms and attachments of the past. Religion, tradition and conventional morality loose their force and class, status, nation and the nuclear family their attraction. Consequently, the young individuals are cognitively and normatively disoriented and search for new social bonds. But for most of them the return to the security of the past is largely forsaken. ${ }^{7}$ Their parents are a product of the sixties and they themselves have largely grown up in situation of relative socioeconomic security. In so far as basic values reflect the conditions that prevailed during one's pre-adult years, it comes as no surprise that Inglehart's theory of the intergenerational value change is empirically confirmed: young people are even more inclined toward post-materialist values than their parents (INGLEHART, 1997: 131-159). Halpern confirms these findings when he notes

\footnotetext{
7 For most of them, because confronted with an 'erosion crisis' (Ziehe) and 'ontological insecurity' (Giddens), a minority of young people hark back to the securities of the past. Some become conventional, others straightforward fundamentalists, and some are drawn to racist and neo-fascist countermovements.
} 
that young people are generally more tolerant, have less respect for traditional values and wish more self-determination and self-responsibility (quoted by WILKINSON, 1997: 90). Those differences between the young and their parents do not result from the fact that people become less tolerant when they grow older but from an acceleration of the intergenerational shift towards postmaterialism. It remains to be seen whether the economic crisis will cause a dent in the long trend to postmaterialism. The preliminary data of the world value survey (2006-2013) are inconclusive. The massive presence of young people in street protests may, however, be interpreted as a violent rejection of materialist values and neoliberal politics of austerity.

Young people are generally more critical and more political than their parents. They are very sensitive to moral issues and refuse to accept the unacceptable, such as racial discrimination, ethnic cleansing, violation of human rights, sexual abuse and the organised irresponsibility towards the environment. They sympathise with the poor and the excluded and join voluntary associations to care for them and to help them survive. They do no longer accept the hypocrisy of the politicians and tend to reject politics, not politics as such but the rituals of the institutionalised party-politics. 'What appears at first sight to be political apathy in fact represents a profound cultural revolution' (COHEN, 1997:181). Young people increasingly withdraw from society but this withdrawal is not without political implications. The apparent de-politicisation of the state goes together with a re-politicisation, or better, to use Beck's terminology, with a 'subpoliticisation' of society (BECK, 1993: 149-171; BECK, GIDDENS and LASH, 1994: 13-23). Subpolitics means shaping from below, challenging the system from within its margins, trying to influence politics and to change the rules of its game by changing values and developing countercultural life-styles. Subpolitics is thus "life politics" (GIDDENS, 1991: 214-231), a politics not so much of life chances but of lifestyles which concerns "disputes about how (as individuals and as collective humanity) we should live in a world where what used to be fixed either by nature or tradition 
is now subject to human decisions" (GIDDENS, 1994: 14-15). Life-politics does not eliminate the "emancipatory politics" that are concerned with life-chances, but it supplements the struggle against exploitation, inequality and oppression with a struggle for morally justifiable forms of life that promote the self-actualisation and self-determination which young people value most. Indeed, the young cohorts of post-materialists are most sympathetic to life-politics, but there are good empirical indications that they do not want to abandon the results of the emancipatory politics of the past (INGLEHART, 1990: 7-12, 248-288). They are less attracted to the Marxist interpretation of society, and although they do not favour an expansion of the welfare state, they do not support the neo-liberal attack on the welfare state either, as they are very much aware that a return to laissez-faire capitalism would undermine their post-materialist aspirations and bring a renewal of the class conflict. At times, they are attracted by anarcho-communism, but this fully consonant with the instable balance between despair and utopia that characterises social upheaval in times of transition. Therefore, if transnational social movements were to emerge to contest the social and ecological effects which the globalisation of the politics of industrial capitalism entails, we could expect to find the young cohorts at their forefront.

\section{References}

ADORNO, T. W. 'Spätkapitalismus oder Industriegesellschaft?', pp. 354-370 in Gesammelte Schriften 8. Frankfurt/Main: Suhrkamp, 1987.

ALBROW, M. The Global Age. State and Society beyond Modernity. Cambridge. Polity Press, 1996.

ALEXANDER, J. C. 'Modern, Anti, Post and Neo: How Social Theories Have Tried to Understand the 'New World' of 'Our Time”, Zeitschrift für Soziologie, 23, 3, 1994, pp. 165-197. 
APPADURAI, A. 'Disjuncture and Difference in the Global Cultural Economy', pp. 295-310 in FEATHERSTONE, M. (ed.), Global Culture. Nationalism, Globalization and Modernity. London: Sage, 1990.

APPADURAI, A. 'Globale ethnische Räume. Bemerkungen zur Entwicklung einer transnationalen Anthropologie', pp. 1140 in BECK, U., Perspektiven der Weltgesellschaft. Frankfurt am Main: Suhrkamp, 1998.

AXFORD, B. The Global System. Economics, Politics and Culture. Cambridge: Polity Press, 1995.

BAUDRILLARD, J. Pour une critique de l'économie politique du signe. Paris: Gallimard, 1972.

BAUDRILLARD, J. Le miroir de la production ou l'illusion critique du matérialisme historique. Paris: Galilée, 1985.

BAUMAN, Z. Postmodernity and its Discontents. Cambridge: Polity Press, 1997.

BAUMAN, Z. Globalization. The Human Consequences. Cambridge, Polity Press: 1998.

BECK, U. Risikogesellschaft. Auf dem Weg in eine Andere Moderne. Franfurt am Main: Suhrkamp, 1986.

BECK, U. Gegengifte. Die organisierte Unerantwortlichkeit. Franfurt am Main: Suhrkamp, 1988.

BECK, U. and BECK-GERNSHEIM, E. Das ganz normale Chaos der Liebe. Frankfurt am Main: Suhrkamp, 1990.

BECK, U. Politik in der Risikogesellschaft. Essays und Analysen. Franfurt am Main: Suhrkamp, 1991.

BECK, U. Die Erfindung des Politischen. Zu einer Theorie reflexiver Modernisierung. Frankfurt am Main: Suhrkamp, 1993.

BECK, U. and BECK-GERNSHEIM, E. (Hgs.). Riskante Freiheiten. Individualisierung in modernen Gesellschaften. Frankfurt am Main: Suhrkamp, 1994. 
BECK, U., GIDDENS, A. and LASH, S. Reflexive Modernisation. Politics, Tradition and Aesthetics in the Modern Social Order. Cambridge: Polity Press, 1994.

BECK, U. Die feindlose Demokratie. Ausgewählte Aufsätze. Leipzig: Reclam, 1995.

BECK, U. Was ist Globalisierung? Irrtümer des Globalismus - Antworten auf Globalisierung. Frankfurt am Main: Suhrkamp, 1997.

BECK, U. (Hg.). Politik der Globalisierung. Frankfurt/Main: Suhrkamp, 1998a.

BECK, U. (Hg.). Perspektiven der Weltgesellschaft. Frankfurt/Main: Suhrkamp, 1998b.

BELL, D. The Coming of Post-Industrial Society: A Venture in Social Forecasting. London: Heinemann, 1974.

BERGER, P. The Sacred Canopy. Elements of a Sociological Theory of Religion. New York: Doubleday, 1969.

BERGER, P., BERGER, B. and KELLNER, H. The Homeless Mind. Modernization and Consciousness. New York: Vintage Books, 1974.

BERGER, P. The Heretical Imperative. Garden City: Doubleday, 1979.

BERMAN, M. All that is solid melts into air. The Experience of Modernity. London: Verso, 1982.

BEST, S. and KELLNER, D. Postmodern Theory. Critical Interrogations. New York: Guildford Press, 1991.

BOURDIEU, P. La distinction. Critique sociale du jugement. Paris: Minuit, 1979.

BOURDIEU, P. Contre-feux. Propos pour servir à la résistance contre l'invasion néo-libérale. Paris: Liber-Raisons d'agir, 1998.

BOYER, R. and SAILARD, Y. (eds). Théorie de la régulation. L'état des savoirs. Paris: La découvert, 2002. 
CAILLÉ, A. Critique de la raison utilitaire. Manifeste du Mauss. Paris: La Découverte, 1988.

CALHOUN, C. 'New Social Movements of Early Nineteenth Century', Social Science History, 17, 3, 1993, pp. 385-427.

CAVALLI, A. and GALLAND, O. (eds.). Youth in Europe. London: Pinter, 1995.

COCKROFT, J., FRANK, A. and JOHNSON, D. Dependence and Underdevelopment. Garden City: Anchor Books, 1972.

COFFIELD, F. 1997, 'Always the Trainee, Never the Employee? Increasingly protracted transitions in the $\mathrm{UK}^{\prime}, \mathrm{pp} .45-62$ in Cavalli, A. and Galland, O. (eds.). Youth in Europe, London: Pinter.

COHEN, J. 'Strategy or Identity: New Theoretical Paradigms and Contemporary Social Movements', Social Research, 52, 4, 1985, pp. 663-716.

COHEN, J. and ARATO, A. Civil Society and Political Theory. Cambridge:. MIT Press, 1992.

COHEN, P. Rethinking the Youth Question. Education, Labour and Cultural Studies. London: Macmillan, 1997.

CROOK, S., PAKULSKI, J. and WATERS, M. Postmodernization. Change in Advanced Societies. London: Sage, 1992.

DEWS, P. Logics of Disintegration. Post-Structuralist Thought and the Claims of Critical Theory. London: Verso, 1987.

DUBET, F. Sociologie de l'expérience. Paris: Seuil, 1994.

EDER, K. The New Politics of Class. Social Movements and Cultural Dynamics in Advanced Societies. London: Sage, 1993.

FALK, R. On Humane Governance. Toward a New Global Politics. Cambridge: Polity Press, 1995. 
FEATHERSTONE, M. 'In Pursuit of the Postmodern', Theory, Culture and Society, 5, 2/3, 1988, pp. 195-215.

FEATHERSTONE, M. (ed.). Global Culture. Nationalism, Globalization and Modernity. London: Sage, 1990.

FEATHERSTONE, M. and LASH, S. 'Globalization, Modernity and the Spatialization of Social Theory', pp. 1-24 in FEATHERSTONE, M., LASH, S. and ROBERTSON, R. (eds.). Global Modernities. London: Sage, 1995.

FORNÄS, J. 'Youth, Culture and Modernity', pp. 1-11 in FORNÄS, J. and BOLIN, G. (eds.). Youth Culture in Late Modernity. London: Sage, 1995.

FREITAG, M. 'La nature dela technique et le problèmenormatif posé par son émancipation contemporaine dans le technologisme et le technocratisme', Société, 4, 1989, pp. 5-94.

FRIEDMAN, J. 'Global System, Globalization and the Parameters of Modernity', pp. 69-90 in Featherstone, M., Lash, S. and Robertson, R. (eds.). Global Modernities. London: Sage, 1995.

GALLAND, O. 'Introduction. What is Youth?', pp. 1-6 in CAVALLI, A. and GALLAND, O. (eds.). Youth in Europe. London: Pinter, 1995.

FURLONG, A. and CARTMEL, F. Young People and Social Change. Individualisation and Risk in Late Society. Buckingham: Open University Press: 1997.

GIDDENS, A. The Constitution of Society. Outline of the Theory of Structuration. Cambridge: Polity Press, 1984.

GIDDENS, A. The Nation-State and Violence. Volume two of a Contemporary Critique of Historical Materialism. Cambridge: Polity Press, 1985.

GIDDENS, A. The Consequences of Modernity. Cambridge: Polity Press, 1990. 
GIDDENS, A. Modernity and Self-Identity. Self and Society in the Late Modern Age. Cambridge: Polity Press, 1991.

GIDDENS, A. Beyond Left and Right. The Future of Radical Politics. Cambridge: Polity Press, 1994.

HABERMAS, J. Legitimationsprobleme im Spätkapitalismus. Frankfurt am Main: Suhrkamp, 1975.

HABERMAS, J. Der philosophische Diskurs der Moderne. Zwölf Vorlesungen. Frankfurt am Main: Suhrkamp, 1985.

HABERMAS, J. 'Jenseits der Nationalstaats? Bemerkungen zu Folgeproblemen der wirtschaftlichen Globalisierung', pp. 67-84 in BECK, U. (Hg.) 1998a, Politik der Globalisierung. Frankfurt/Main: Suhrkamp, 1998a.

HABERMAS, J. Die postnationale Konstellation. Politische Essays. Frankfurt/Main: Suhrkamp, 1998b.

HALL, S. 'The Question of Cultural Identity', pp. 273-316 in HALL, S., HELD, D. and McGREW, T. (eds.). Modernity and its Futures. Cambridge: Polity Press, 1992.

HONNETH, A. "Pathologien des Sozialen. Tradition und Aktualität der Sozialphilosophie", pp. 11-87 in Das Andere der Gerechtigkeit. Aufsätzen zur praktischen Philosophie. Frankfurt am Main: Suhrkamp, 2000.

HANNERZ, U. 'Cosmopolitans and Locals in World Culture', pp. 237-251 in FEATHERSTONE, M. (ed.). Global Culture. Nationalism, Globalization and Modernity. London: Sage, 1990.

HEELAS, P., LASH, S. and MORRIS, P. (eds.). Detraditionalization. Critical Reflections on Authority and Identity. Oxford: Blackwell, 1996.

HELD, D. 'Democracy, the Nation-State and the Global System', pp. 197-235 in Held, D. (ed.). Political Theory Today. Cambridge: Polity Press, 1991. 
HELD, D. Democracy and the Global Order. From the Modern State to Cosmopolitan Governance. Cambridge: Polity Press, 1995.

HIRST, P. and THOMPSON, G. Globalisation in Question. The International Economy and the Possibility of Governance. Cambridge: Polity Press, 1996.

HORKHEIMER, M. and ADORNO, T.W. (1948). Dialektik der Aufklärung. Philosophische Fragmente. Frankfurt am Main: Fisher, 1986.

INGLEHART, R. The Silent Revolution: Changing Values and Political Styles. Princeton: Princeton University Press, 1977.

INGLEHART, R. Culture Shift in Advanced Industrial Society. Princeton: Princeton University Press, 1990.

INGLEHART, R. Modernization and Postmodernization. Cultural, Economic, and Political Change in 43 Societies. Princeton: Princeton University Press, 1997.

INGLEHART, R. "Changing Values among Western Publics from 1970 to 2006", West European Politics, 31, 1-2, 2008, pp. 130-146.

JAMESON, F. Postmodernism or, the Cultural Logic of Late Capitalism. London: Verso, 1991.

KNÖBL, W. Spielräume der Modernisierung. Das Ende der Eindeutigkeit. Weilerswist: Velbrück Verlag, 2001.

LASH, S. and URRY, J. The End of Organized Capitalism. Cambridge: Polity Press, 1987. LASH, Sociology of Postmodernism. London: Routledge, 1990.

LASH, S. and URRY, J. Economies of Signs and Space. London: Sage, 1994.

MANNHEIM, K. 'Das Problem der Generationen', pp. 509-565 in Wissenssoziologie. Auswahl aus dem Werk. Berlin: Luchterhand, 1964.

McGREW, A. 1992, 'A Global Society', pp. 61-153 in Hall, S., Held, D. and McGrew, A. (eds.). Modernity and its Futures. Cambridge: Polity Press, 1992. 
McGREW, A. (ed.). The Transformation of Democracy? Globalization and Territorial Democracy. Cambridge: Polity Press, 1997.

MELUCCI, A. Nomads of the Present. Social Movements and Individual Needs in Contemporary Society. London: Hutchinson, 1989.

MELUCCI, A. Challenging Codes. Collective Action in the Information Age. Cambridge: Cambridge University Press, 1996.

MILLS, C.W. The Sociological Imagination. Oxford: Oxford University Press, 1957.

MOORE, B. The Social Origins of Dictatorship and Bureaucracy. Boston: Beacon Press, 1966.

NEDERVEEN PIETERSE, J. 'Globalization as Hybridization', pp. 45-68 in Featherstone, M., Lash, S. and Robertson, R. (eds.). Global Modernities. London: Sage, 1995.

OFFE, C. Disorganized Capitalism. Contemporary Transformations of Work and Politics. Cambridge: Polity Press, 1985a.

OFFE, C. 'New Social Movements: Challenging the Boundaries of Institutional Politics', Social Research, 1985, 52, 4, 1985b, pp. 817-868.

PARSONS, T. Societies. Comparative and Evolutionary Perspectives. Englewood Cliffs: Prentice-Hall, 1966.

PARSONS, T. The Evolution of Societies. Englewood Cliffs: Prentice Hall, 1977.

ROBERTSON, R. Globalization. Social Theory and Global Culture. London: Sage, 1992.

ROBERTSON, R. 'Glocalisation: Time-Space and HomogeneityHeterogeneity, pp. 25-44 in Featherstone, M., Lash, S. and Robertson, R. (eds.). Global Modernities. London: Sage, 1995.

ROSENAU, J. 1990, Turbulence in World Politics. A Theory of Change and Continuity. Princeton: Princeton University Press, 1990. 
SCHELSKY. 'Ist die Dauerreflexion institutionalisierbar?', pp. 250-276 in Auf der Suche nach der Wirklichkeit. Düsseldorf: E. Diederichs Verlag, 1965.

SCHILLER, H. Mass Communications and American Empire. Boston: Beacon Press, 1969.

SKLAIR, L. Sociology of the Global System. London: Prentice Hall, 1991.

SMART, B. Modern Conditions, Postmodern Controversies. London: Routledge, 1992.

SZTOMPKA, P. The Sociology of Social Change. Oxford: Blackwell, 1993.

THOMPSON, J. The Media and Modernity. A Social Theory of the Media. Cambridge: Polity Press, 1995.

VANDENBERGHE, F. Une histoire critique de la sociology allemande. Aliénation et réification. Vol. 1: Marx, Simmel. Weber, Lukacs. Vol. 2: L'Ecole de Francfort et Habermas. Paris: Editions de la Découverte, 1997-1998.

VANDENBERGHE, F. What's Critical about Critical Realism? Essays in Reconstructive Social Theory. London: Routledge, 2014.

WACQUANT, L. Punishing the Poor: The Neoliberal Government of Social Insecurity. Durham: Duke University Press, 2009.

WATERS, M. Globalization. London: Routledge, 1995.

WEBSTER, F. Theories of the Information Society. London: Routledge, 1995.

WILKINSON, H. "Kinder der Freiheit. Ensteht eine neue Ethik individueller und sozialer Verantwortung?", pp. 85-123 in BECK, U. (Hg.). Kinder der Freiheit. Frankfurt am Main: Suhrkamp, 1997.

Recebido em 19/09/13.

Aprovado em 20/03/14. 